\title{
乳幼児生体肝移植後の狭窄および血栓閉塞に対する エコー透視下のカテーテルインターベンション
}

\section{前田孝雄 木村好文 黒田千夏 高野友美子 ${ }^{11} \quad$ 瀬尾害(正 ${ }^{12}$ 藤栄寿雄 ${ }^{21}$}

【要旨】乳幼児の生体肝移植後の合併症である血管吻合部の狭管や血栓閉塞に対し, 経皮的カテー テルインターベンション（バルーン拡張術ょよび血怪吸引術）を安全かつ確実に行うことができた。 各手技の施行中は治療前後に血管造影および圧力測定を行い, 治療効果を確認した。また, 各手技 は 30〜40 分程度であったが, その施行中柱術者, 麻酔医, 放射線技師, 看讙師, 臨床工学技士が綿 密な裹䊀を取り合い, 血行動管, 血液ガスなどをチェックしながら, 安全に施行できるように努め た。肝移植後の全身状態が不安定な乳幼児の肝静眽の狭䆧や血栓症に対する超音波エコー透視下の カテーテルインターベンションは, 乳幼児への負担が少ない低侵缺手技であり, 造影および静脈圧

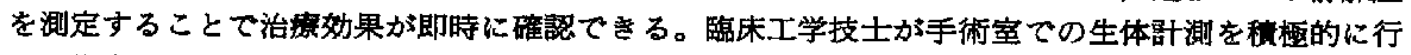
い, 術者, 麻酔医, 放射線技師, 着護師とともに, その手技の手順と注意点を理解し, 綿密な連絡 を取り合うことが安全に行うための重要なポイントである。

Key words : 生体䀒穆植, 経皮的バルーン拡張術, 血栓吸引術

\section{I. 緒 震}

近年, 多くの施設で乳幼児の生体肝移植が行われ るようなり，それに伴う術後合併症の発生も少なく なってきている”。今回我々は, 術後に発生した血管 吻合部の狭窟や血栓開塞に対し，エコー透視下に上 る経皮的バルーン拡張術（以下，PTA）および血栓 吸引術を安全かつ確実に行うことができたので，症 例の提示と手技中の重要なポイントについて報告す る。

\section{II. 症例および方法}

症例 1：先天性胆道閉塞症とアラジール症候群を 合併している 10 っの女坚, 身長 $66.8 \mathrm{~cm}$ 体重 $8.86 \mathrm{~kg}$ 。生体肝移植を施行, 術後 76 日加ら 90 日前 後に, 肝静脈・下行大静脈吻合部付近の狭窄および 血栓閉塞に対してPTAおよび血栓吸引術を施行し た。

症例 2 : 先天性胆道䦙塞症の 1 歳 5 ヶ月の女览, 身曼 $89.4 \mathrm{~cm}$ 体重 $13.43 \mathrm{~kg}$, 生体肝移植を施行, 術 後 215 日前後に, 吻合部狭窄を認めPTAを施行し た2)(表 1)。

全身啝醉下に超音波エコーガイド下にて，肝静脈 を穿刺し(図 1)，経皮的シースを捕入してバルーン カテーテルもしくは吸引カテーテルを捙入した。拡

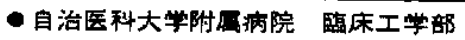

1)自治医科大学 麻酔科学・焦中治症医和神座

2) 同 放射線科学新座

\begin{tabular}{|c|c|c|}
\hline & 小湂 1 & 小片 2 \\
\hline III & (F) & (F) \\
\hline$\Rightarrow \quad \frac{1}{2}(\mathrm{~cm})$ & 66.8 & 89.4 \\
\hline 体工 $(\mathrm{kg})$ & 8.865 & 13.43 \\
\hline 年跑(y.m) & $10 \mathrm{~m}$ & $1 y 5 m$ \\
\hline$P T A(n)$ & $n=3$ & $\overline{n=6}$ \\
\hline 血栓眼 $/(n)$ & $\bar{n}=5$ & $n=0$ \\
\hline
\end{tabular}

張術（以下, PTA) は Ultra-thin Diamond Balloon Dilatation-catheter $5 \mathrm{Fr}, 40 \mathrm{~cm}$, balloon (Boston 社製), 血栓吸引術江 OASIS ${ }^{\mathrm{TM}}$ Thrombectomy System $6 \mathrm{Fr}, 65 \mathrm{~cm}$ (Boston 社製) を使用した (表 2)。狭窟部前後の肝静脈圧を測定しながらパルーン 拉張術 $(6 \sim 8 \mathrm{~mm}$ バルーン径, 6 気圧 $30 \mathrm{sec}$ )を $3 \sim 6$ 回施行した ${ }^{3)}$ (図 2)。刵静脈造影はイオパミ

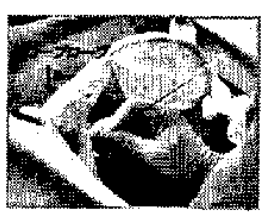

・エコー下にて穿制

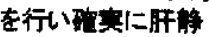
眽に掉入する

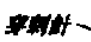

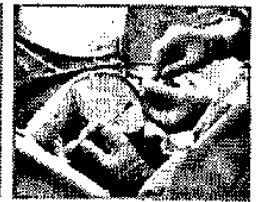

・ガイトワイヤーを同 ヒくエコ一下に推入 L.TWK

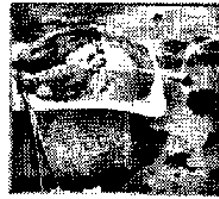

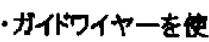
用し、カテーテルに 究あった イントロデューサを

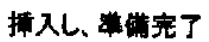




\begin{tabular}{|c|c|}
\hline 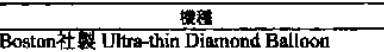 & PTA \\
\hline Dilatation-catheter $5 \mathrm{Fr} 40 \mathrm{~cm}$ balloor $(5 \mathrm{~mm})$ & \\
\hline $\begin{array}{l}\text { Boston 社 OASIS }{ }^{\mathrm{TM}} \text { Thrombectomy System } \\
6 \mathrm{Fr} 65 \mathrm{~cm}\end{array}$ & 血栓吸引 \\
\hline
\end{tabular}

ロンを Hand injection DSAにて行い，狭窄部位の 著明な拡㖘が確認された(図 3)。また, 肝静脈圧の 改善も見られた。血栓閉塞に対しては，吸引術 ${ }^{41}$ は生 食を注入することで陰压を発生させ吸引するカテー テルを使用し, 生食注入速度 $2.5 \mathrm{~mL} / \mathrm{sec}$, 最大許容 圧力 $850 \mathrm{psi}$ を基準に, 1 回に付き 30 秒から 60 秒 を 5 回施行した（図 4)。

III. 結 果

PTAの成果を治療前と治療後の肝静脈造影にて 比較した。狭宫部位は, 径 $5 \mathrm{~mm}$ 程度に拡張してい た（図 3)。

肝静脈圧波形と右房圧波形を図 5 に示す。㹡張前 の圧力波形は，脈圧がほとんどなくフラットであっ たが, 拡張後に圧力が低下して右房圧と同じ波形を 呈し，a 波, $\mathrm{v}$ 波がはっきりと認識できた。また，吻

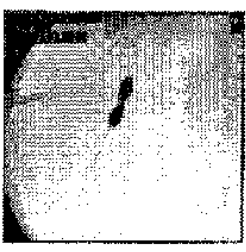

図 2 Balloon 搪張泪 (PTA)

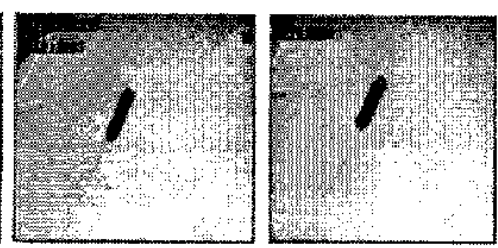

的珎

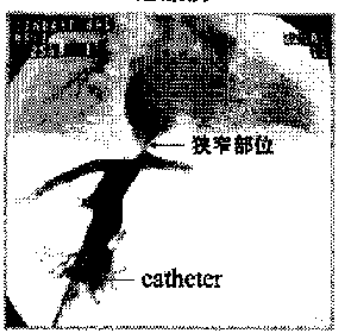

- catheterよりイオパロ Hand injection DSA

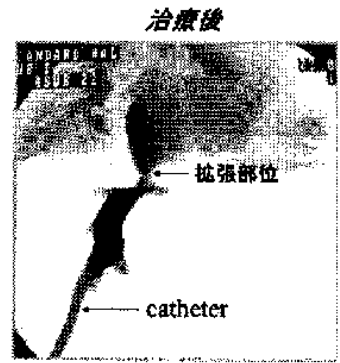

- catheterよりイオパミロン Hand infection DSA
图 3 肝静脈造影
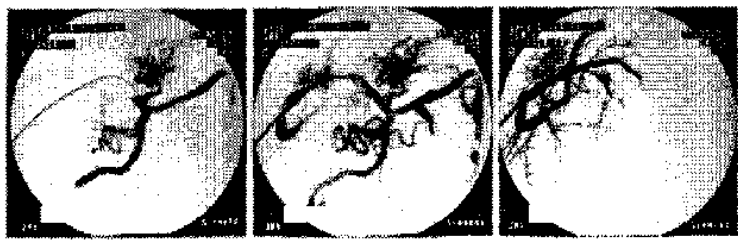

图 4 門脈造影
合部が右房に隣接しているため压力波形は a 波、、 波の右房王と同じく拡張後, 肝静脈血流の増加に上 り圧力の増加が見られた。これは PTA 最終での記 録であった。

血栓吸引術の成果は，大変難しく，血栓の範囲に 時間と技術を要した ${ }^{5}$ 。乳幼肾の血液を多く採取す ることは，出血と同じことになることから，絶えず 手技量 (生食と血液)を，確認しながら施行した（図 6)。また, 血液ガスデータも術前・術後でチェック を行った（図 7)。

\section{IV. 考 察}

PTAおよび血栓吸引術を行う上での注意点を以 下にまとめる。

1.PTA および血栓吸引術は全身麻酔下エコーお よび透視下に行う（図 1)。

2. 狭菅部および閉塞部での造影と圧湘定を行う
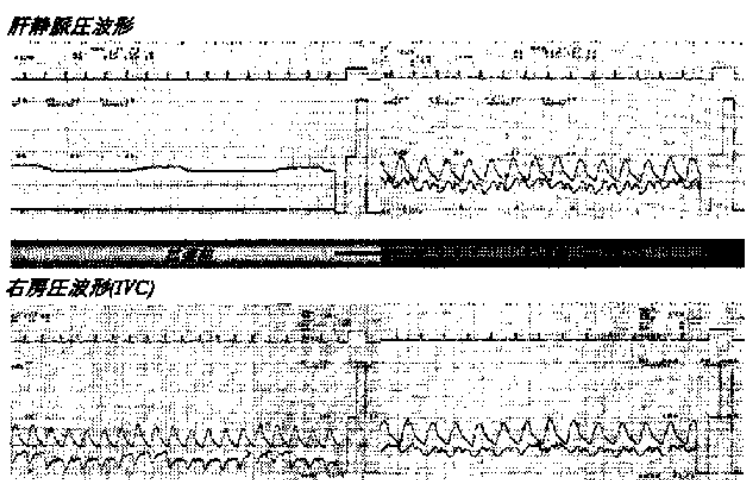

图 5 Pressure data

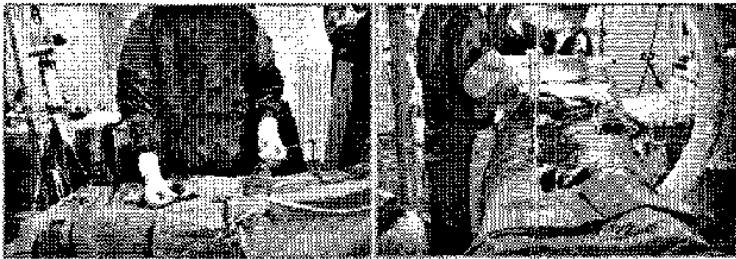

图 6 血栓吸引治療術

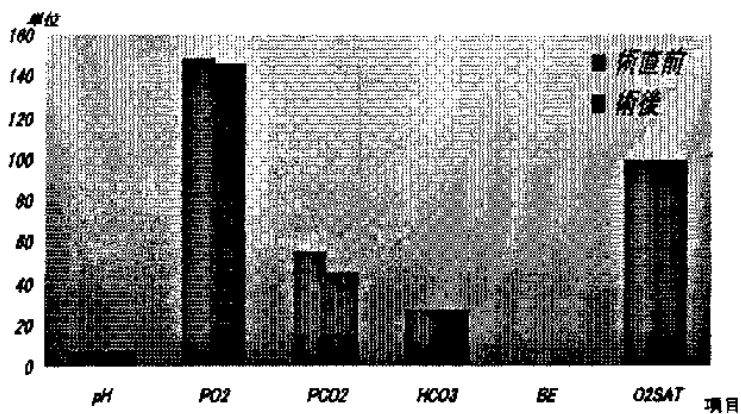

図 7 Blood gas data 
(図 5)。これは，造影による血管拡張の確㽝ととも に静脈内压の低下を評価することにより，手技の成 功度を判断することができる。確实に血管を㹡張し た指標と評価てきる。

3. バルーン拡張期および吸引時には血行動態の変 娌, 出血に注意する。血管を搪張している時間は, 血行が途絶えている。また，吸引時は出血量を把挃 しながら行うの。

4.血栓吸引術は血栓部位が舆くなれぼなるほど, 時間と技術を要する。乳幼児の血液を多く採取する ことは，出血と同じであり，絶えず手技中の生食注 入量と吸引した血液量の出納バランスを算出した (圆 6)。

5. 血液ガスデータも随時チェックすることが必要 である(図 7)。

6. 压力の偏移を美圧で表す。肝静脈圧においては, 治瘄前 $20.3 \pm 5.0 \mathrm{mmHg}$ が治瘄後 $10.95 \pm 4.0$ $\mathrm{mmHg}$ ，右心房圧は， $5.8 \pm 2.5 \mathrm{mmHg}$ が治療後 $10.2 \pm 2.0 \mathrm{mmHg}$ と変化しており, 差压は, 14 $\mathrm{mmHg}$ が $1 \mathrm{mmHg}$ と治療前は大きな差圧が治療

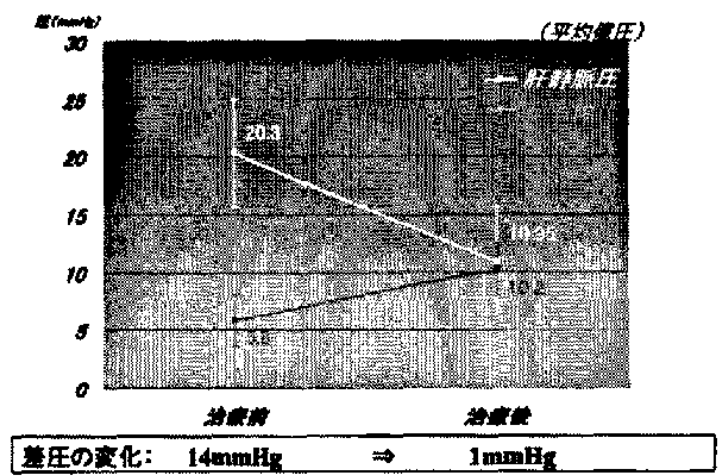

图 8 圧力侕移（差压）

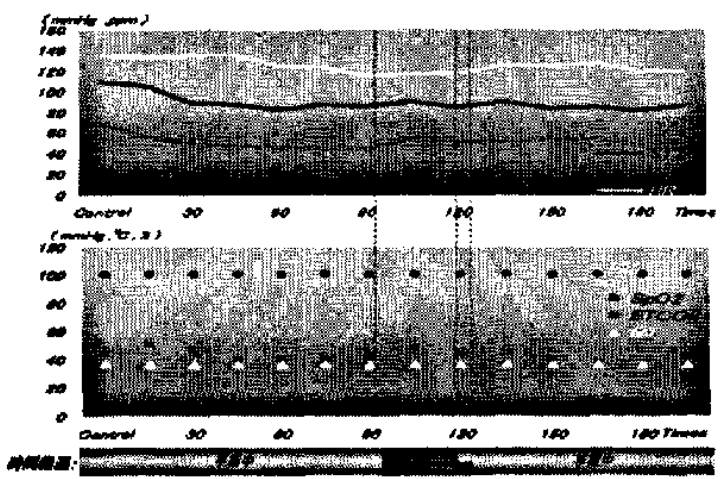

图 9 血行動態
後は活とんど羑がないことが分かる（図 8)。

7. 綝り返し必要な場合は, 循環動態の安定するの を待って行ら。こ机らを注意しながら行うことで, 安定した血行動態が維持できる（図 9 ）。

8. 医師 (術者, 麻酔医), 看護師, 放射線技師, 臨 床工学技士と意思疎通を図りながら施行する。

V. 結 唔

乳幼児生体肝移植後の合併症である肝髅脈狭萓と 血拴症に対して，エコー透視下で経皮的バルーン拡 張術および血栓吸引術を安全かつ確実に行うことが できた。これらの手技は低侵㜔で乳幼児の血行野照 の変化も少なく安定して行えることが判明した。

臨床工学技士が手術室での生体計測を積極的に行 い, 術者，麻酔医，放射線技師，看讙師とともに， その手技の手㜊と注意点を理解し，綿密な連絡を取 り合うことが安全に行うための重要なポイントであ る。

\section{○伀考文嘀}

1) 白井勇作, 吉治仁志, 藤本正男: 経皮的血管形成術 (PTA)により救哈し得た急性型 Budd-Chiari 症候 群の1例。日本消化器病学会, 第 80 回例会近被支部。

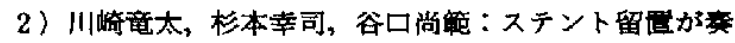
功した生体肝移植後の肝静膔一下大静脈狭窝の 1 例. 日本血管造影 IVR 学会, 第 15 回䦔西（第 36 回関西 IVR 研究会）地方会。

3）中西征司，道暁浩二郎，武智俊治：Percutaneous transluminal angioplastyにより是道・早静脈櫭が消 失した Budd-Chiari 症堠群の 1 例。日本消化器内視鏡 学会雑誌, 46(1)：47, 2004.

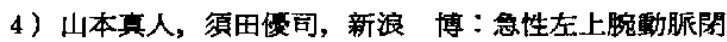
塞症に対して Oasis ${ }^{T M}$ 血栓吸引カテーテルで治敞した 1 例 THE JOURNAL of JAPANESE COLLEGE of ANGIOLOGY, $44(12)$.

5) 戸島雅宏，西谷 泰，出町洋他：急性動脈閉塞症に 対するカテーテル血栓溶解療法の意義一手術例と比 較して一。日血外会誌，9；491-497，2000。

6）芹川 威, 角田 修, 森 卓他：血栓吸引カテーテ ル (Oasis ${ }^{\mathrm{TM}}$ ) と経皮的心肺補助装置 (PCPS) の使用 にて救命しえた院内発症肺血栓塞栓症の1例. 舜床と 研究, $79 ; 139-142,2002$.

$\left.\begin{array}{l}\text { 本論文は，第 } 31 \text { 回日本体外质環技術研究会大会にて } \\ \text { 報告した。 }\end{array}\right]$ 